\title{
Production of hydrolysate from processed Nile tilapia (Oreochromis niloticus) residues and assessment of its antioxidant activity
}

\author{
Daniela Miotto BERNARDI ${ }^{1 *}$, Leandro Daniel de PARIS², Fabiana DIETERICH ${ }^{2}$, \\ Fernanda Guimarães Dummond e SILVA ${ }^{1}$, Wilson Rogério BOSCOLO ${ }^{3}$, Cezar SARY ${ }^{3}$, Altevir SIGNOR ${ }^{3}$, \\ Teresinha Marisa BERTOL ${ }^{4}$, Valdemiro Carlos SGARBIERI ${ }^{1}$
}

\begin{abstract}
The objective of this work was to produce protein hydrolysates from by-products of the Nile tilapia fileting process, and to assess the effects of different hydrolysis times on the antioxidant activity of the hydrolysed animal-based protein, in free form and incorporated into a food matrix. Gutted tilapia heads and carcasses were hydrolysed by Alcalase ${ }^{\circledR}$ for different hydrolysis times producing six hydrolysates. The protein content, degree of hydrolysis, reverse-phase high-performance liquid chromatography, and antioxidant activity by the ORAC, FRAP and TEAC methods were analysed. Three mini-hamburger formulations were produced and the lipidic oxidation of mini-hamburger was determined by TBARS. The protein contained in the residue was completely recovered in the process. The hydrolysates varied in their degree of hydrolysis, but presented similar levels of antioxidant activity. In the mini-hamburgers the hydrolysate was capable of delaying oxidation after 7 days of storage. Hydrolysis of tilapia processing by-products produced peptides may be used in the formulation of functional foods.
\end{abstract}

Keywords: fish; protein; hydrolysis; antioxidants.

Practical Application: The practical application of this work is the production of peptides with antioxidant activity using protein recovery from a raw material considered a residue or by-product of Nile Tilapia processing.

\section{Introduction}

Antioxidants play an important role in the reduction of the oxidative process, both in food systems and in the human body. In foodstuffs, its use contributes towards delaying lipidic and protein oxidation, helping to maintain the colour, aroma, taste, texture and nutritional value of food products (Bernardi et al., 2016). In the human body the presence of antioxidants, whether endogenous or exogenous, reduces oxidative damage caused by reactive oxygen and nitrogen species, thus reducing the risk of developing certain diseases (Samaranayaka \& Li-Chan, 2011).

Due to questions regarding the safety of using synthetic substances in food, there has been a growing interest in identifying natural compounds that possess antioxidant properties and can be used as natural additives in food or as physiological-functional ingredients in food products (Bernardi et al., 2016). Of the compounds studied, the bioactive peptides stand out, since they can be produced from several protein sources and through different methods (enzymatic hydrolysis, digestion in the gastrointestinal tract and microbial fermentation), as well as being considered safe, nutritionally healthy, low cost and highly antioxidant (Samaranayaka \& Li-Chan, 2011).
The production of bioactive peptides from the hydrolysis of fish product proteins is feasible and intensely studied primarily due to the wide availability of this raw material (Samaranayaka \& Li-Chan, 2011). In this context, the Nile tilapia (Oreochromis niloticus) is a freshwater fish whose intensive breeding has increased substantially in recent years (Roslan et al., 2014), with the filet being its product of greatest commercial value. The head, carcass, bones, skin, fins and viscera represent roughly 60 to $70 \%$ of the weight of the tilapia, considered waste or by-products of its processing, which if not properly discarded or used, can have a significant environmental impact, bearing in mind the considerable volume (Roslan et al., 2014; Silva et al., 2014). These residues are sources of high nutritional value protein, therefore making use of them is of nutritional, economic and environmental interest (Roslan et al., 2014; Silva et al., 2014).

As mentioned above, enzymatic hydrolysis of proteins produces peptides with antioxidant potential. Furthermore, it's a form of transforming raw material and, therefore, can be used as an alternative for recycling tilapia processing residues. Hence, the objective of this work was to produce a hydrolysate at a pilot industrial plant from the by-product of the fileting process of

${ }^{1}$ Departamento de Alimentos e Nutrição, Faculdade de Engenharia de Alimentos, Universidade Estadual de Campinas - UNICAMP, Cidade Universitária "Zeferino Vaz", Campinas, SP, Brazil 
Nile tilapia, to evaluate the effect of the hydrolysis time on the protein recovery of the material and on the in vitro antioxidant activity, as well as to assess the capacity of the hydrolysate to maintain the oxidative stability of a meat product.

\section{Materials and methods}

\subsection{Production of the hydrolysate}

The hydrolysate was produced with by-products resulting from the fileting process of Nile tilapia. The head and gutted carcass were used, supplied by the company Falbom Agroindustrial Ltda. (Toledo-PR-Brazil). The hydrolysis was performed in accordance with the description given by Dieterich et al. (2014).

Tilapia heads and carcasses were ground in a meat grinder $(5.0 \mathrm{~mm})$ and placed in an industrial reactor equipped with an electric heater. The composition was $80 \%$ ground material (head and gutted carcass) and 20\% water. The material was homogenized and heated up to $50^{\circ} \mathrm{C}$, at which time the Alcalase ${ }^{\circledR}$ (2.75 AU-A/g) from Bacillus licheniformis (Novozymes Latino Americana Ltda., Paraná, Brazil) was added at a proportion of $0.2 \%(\mathrm{w} / \mathrm{w})$. The total duration of the hydrolysis was 240 minutes and the homogenization process remained constant until the end of the reaction. The temperature and $\mathrm{pH}$ were monitored and controlled throughout the hydrolysis process, the temperature varied from $50{ }^{\circ} \mathrm{C}$ to $64^{\circ} \mathrm{C}$ and the $\mathrm{pH}$ varied between 5.8 and 6.1. Every 40 minutes of reaction 2 litre samples of the hydrolysate were collected, which were subjected to thermal inactivation of the enzyme (heated to $90^{\circ} \mathrm{C}$ for 10 minutes) and filtered (through a $1 \mathrm{~mm}$ mesh screen) to remove remaining bones. By the end, samples with six different hydrolysis times had been obtained: H40) $40 \mathrm{~min}, \mathrm{H} 80) 80 \mathrm{~min}, \mathrm{H120}) 120 \mathrm{~min}, \mathrm{H160}) 160 \mathrm{~min}$, H200) $200 \mathrm{~min}$ and H240) $240 \mathrm{~min}$.

Half of each portion of hydrolysate was frozen in an aluminium tray and lyophilized (Liobrás Freeze-Dryer, model LP810) and named whole lyophilized hydrolysates (WLH). The other half was centrifuged at $13700 \mathrm{x}$ g for 30 minutes in RC5C centrifuge (Sorvall Instruments Dupont, Wilmington, USA) with the temperature controlled at $20^{\circ} \mathrm{C}$ to $26^{\circ} \mathrm{C}$. The insoluble material was discarded and the soluble material was frozen and lyophilized in the same conditions as cited above, these products were named centrifuged lyophilized hydrolysates (CLH). All the hydrolysates were frozen and stored $\left(-20^{\circ} \mathrm{C}\right)$ in hermetically sealed pots until they were analysed and all the assays were carried out in triplicate. The complete flow chart of the processing and analysis of the products is shown in Figure 1.

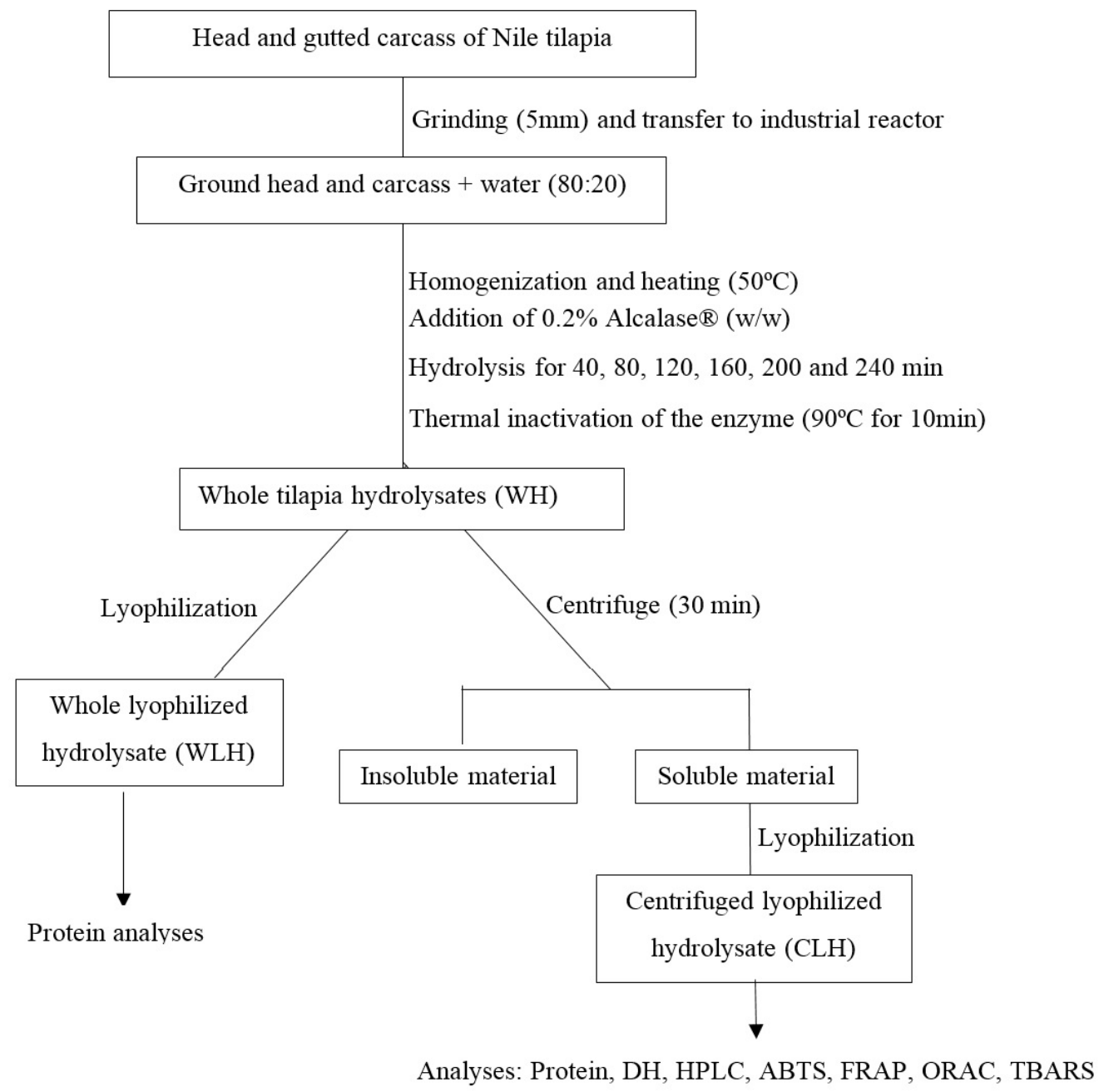

Figure 1. Flow chart of the processing of Nile tilapia carcasses hydrolysates. 


\subsection{Determination of protein and Degree of Hydrolysis (DH)}

The protein content of the samples was determined according to Kjeldahl methodology described by the Association of Official Analytical Chemists (1995), considering a factor of 6.25 for the conversion of $\% \mathrm{~N}$ to protein $(\mathrm{N} \times 6.25)$.

The degree of hydrolysis $(\mathrm{DH})$ is defined as the percentage of cleaved peptide bond: $\mathrm{DH}(\%)=(\mathrm{h} / \mathrm{htot}) \mathrm{x} 100$. Where, $\mathrm{h}$ is the number of hydrolysed bonds and htot is the total number of peptide bonds per equivalent of the protein studied.

The DH was determined by the o-phthaldialdehyde (OPA) method (Nielsen et al., 2001). This method is based on the reaction of primary amino groups with OPA, using serine as the standard solution. Briefly, the OPA reagent was prepared with 3.81 g sodium tetraborate decahydrate and $100 \mathrm{mg}$ sodium dodecyl sulfate dissolved in $80 \mathrm{~mL}$ deionized water added of $88 \mathrm{mg}$ dithiothreitol. Eighty mg OPA was dissolved in $2 \mathrm{~mL}$ ethanol, mixed with the above solution and the volume completed with $100 \mathrm{~mL}$ with distilled water. Twenty $\mathrm{mg}$ serine was dissolved in $200 \mathrm{~mL}$ deionized water $(0.9516 \mathrm{mmole} / \mathrm{L})$. Three $\mathrm{mL}$ OPA reagent was added into $400 \mu \mathrm{L}$ of serine standard solution or protein hydrolysate, mixed for 5 seconds and incubated for 2 minutes at room temperature. The absorbance was spectrophotometrically measured at $340 \mathrm{~nm}$.

\subsection{High-performance liquid chromatography (HPLC)}

For the characterization of protein in the centrifuged lyophilized hydrolysates (CLH) chromatographic analysis (HPLC) was carried out using a high-performance liquid chromatography system with an automatic injector and a diode-array absorbance detector (Agilent, 1200 Series, Washington, USA). Separation was carried out on a Luna C18 column (250 mm x $4.6 \mathrm{~mm}$, Phenomenex, Torrance, CA) at a flow rate of $1 \mathrm{~mL} / \mathrm{min}$. The mobile phase was composed of solvent A ( $0.04 \%$ trifluoroacetic acid in water) and solvent $\mathrm{B}(0.03 \%$ trifluoroacetic acid in acetonitrile). The gradient was from 0 to $80 \%$ of solvent B over $40 \mathrm{~min}$. The absorbance was measured at 214 and $280 \mathrm{~nm}$. The hydrolysates $(8 \mathrm{mg} / \mathrm{mL})$ were filtered through a $45-\mu \mathrm{m}$ membrane and $50 \mu \mathrm{L}$ were injected. The Star Chromatography Workstation software (Agilent) was used for recording and processing the data.

\subsection{Determination of antioxidant activity}

The antioxidant capacity of the hydrolysates (CLH) was measured in an aqueous extract. To obtain the extract, the powdered samples were suspended in deionized water $1 \%(\mathrm{w} / \mathrm{v})$. The extracts were homogenized for 30 minutes, centrifuged in RC5C (Sorvall Instruments Dupont, Wilmington, USA) at $35735 \mathrm{x} \mathrm{g}\left(30 \mathrm{~min}, 10^{\circ} \mathrm{C}\right)$, then filtered in a Whatman \# 1 filter and stored in a dark environment at $-20^{\circ} \mathrm{C}$. Three repetitions of the aqueous extract were produced for each hydrolysate.

The Oxygen Radical Absorbance Capacity (ORAC) method was employed according to the description given by Dávalos et al. (2004). A microplate was used to mix $20 \mu \mathrm{L}$ of the sample extract (or blank, or standard solutions), $120 \mu \mathrm{L}$ of sodium fluorescein (dissolved in potassium phosphate buffer $\mathrm{pH} 7.4$, in the final concentration of $0.378 \mu \mathrm{g} / \mathrm{mL})$ and $60 \mu \mathrm{L} \mathrm{AAPH} \mathrm{[(2.2'-azobis}$ (2-methylpropionamidine) dihydrochloride) were dissolved in water in the final concentration of $108 \mathrm{mg} / \mathrm{mL}$ ]. The potassium phosphate buffer was used as blank. Trolox (6-hydroxy-2,5,7,8tetramethylchroman-2-carboxylic acid) solutions $(25-800 \mu \mathrm{M})$ were used as standard. Fluorescence was measured every minute for 80 minutes using the microplate reader (Synergy ${ }^{\mathrm{Tm}}$ HT Multi-Mode Microplate Reader, Biotek ${ }^{\circledR}$, Vermont, USA) with a 485-nm excitation filter, $520 \mathrm{~nm}$ emission and reaction temperature of $37^{\circ} \mathrm{C}$. The calculation was based on the area under the curve (AUC) formed by the decline in fluorescence over time. The results were expressed in $\mu \mathrm{M}$ of Trolox equivalent (TE) per gram ( $\mu \mathrm{M} \mathrm{TE} / \mathrm{g})$ of sample.

Measuring antioxidant activity through Ferric Reducing Antioxidant Power (FRAP) was carried out in accordance with the methodology described by Benzie \& Strain (1996). In a dark environment, $30 \mu \mathrm{L}$ of the sample extract (or blank, or standard solutions) were mixed into $90 \mu \mathrm{L}$ of water and $900 \mu \mathrm{L}$ of the FRAP reagent with the following composition: $450 \mu \mathrm{L}$ of acetate buffer $0.3 \mathrm{M}$ and $\mathrm{pH} 3.6 ; 225 \mu \mathrm{L}$ of TPTZ $10 \mathrm{mmol}$ in $40 \mathrm{mmol}$ of $\mathrm{CLH}$ and $225 \mu \mathrm{L}$ of $\mathrm{FeCl}_{3} 20 \mathrm{mmol}$. The mixture was incubated at $37^{\circ} \mathrm{C}$ for 30 minutes. The reading was made at 593 nm (Synergy $^{\text {mix }}$ HT Multi-Mode Microplate Reader, Biotek ${ }^{\circledR}$, Vermont, USA). FRAP was calculated from the Trolox standard curve (100-1600 $\mu \mathrm{M})$ and expressed $\mu \mathrm{M}$ TE/g of sample.

The determination of Trolox equivalent antioxidant capacity (TEAC) measured by the 2,2'-Azinobis(3-ethylbenzothiazoline-6sulfonic acid) (ABTS) radical cation was conducted in accordance with the method described by Re et al. (1999). The ABTS radical $\left(\mathrm{ABTS}^{*+}\right.$ ) solution was produced by reacting $5 \mathrm{~mL}$ of the ABTS stock solution $(7 \mathrm{mM})$ with $88 \mu \mathrm{L}$ of the potassium persulfate solution $(140 \mathrm{mM})$. The mixture was allowed to react in the dark for $16 \mathrm{~h}$ at room temperature. Prior to assay, $1 \mathrm{~mL} \mathrm{ABTS}{ }^{-+}$solution was diluted with ethanol to obtain an absorbance of 0.70 at $734 \mathrm{~nm}$. To initiate the reaction, $15 \mu \mathrm{L}$ of sample extract (or blank, or standard solutions) was mixed with $1.5 \mathrm{~mL}$ of $\mathrm{ABTS}^{\cdot+}$ solution, and after 6 minutes absorbance was read at $734 \mathrm{~nm}$ (Synergy ${ }^{\mathrm{rm}}$ HT Multi-Mode Microplate Reader, Biotek ${ }^{\circledR}$, Vermont, USA). Trolox standard curve $(25-1000 \mu \mathrm{M})$ was prepared and the results were expressed in $\mu \mathrm{M} \mathrm{TE} / \mathrm{g}$ of sample.

\subsection{Antioxidant effect in meat product}

Mini hamburgers of pork meat and pork fat were made, using loin and backfat with the addition of $3 \%$ of flaxseed oil in the diet. The average percentage of polyunsaturated fatty acids (PUFA) in the ether extract of the backfat was $23.16 \pm 0.97 \%$ and of the loin $15.79 \pm 0.84 \%$ and the average percentage of $\omega-3$ in the ether extract of these two cuts was $5.33 \pm 0.34 \%$ and $2.81 \pm 0.08 \%$, respectively. Considering the results obtained for the antioxidant activity of the product, the H200 sample of the centrifuged lyophilized hydrolysates $(\mathrm{CLH})$ was selected to be added to the meat product.

Loin, backfat and $\mathrm{NaCl}$ were weighed in the proportions of $78.4 \%, 19.6 \%$ and $2 \%$, respectively. Three formulations of mini hamburgers were produced: MHC: control (no added antioxidant); $\mathrm{MHH}$ : with addition of $1 \%(\mathrm{w} / \mathrm{w})$ of centrifuged 
and dry hydrolysate (H200); MHBHT: with addition of 0.02\% (w/w) of butylhydroxytoluene (BHT).

The meat and backfat were placed, together with the $\mathrm{NaCl}$ and other ingredients, into a domestic food processor (Philips Walita, model Ri1364, Brazil) for 30 seconds. In sequence the samples were weighed in portions of $12.5 \mathrm{~g}$ and moulded. At the end they were placed in individual plastic bags and maintained in the presence of oxygen under refrigeration $\left(4^{\circ} \mathrm{C}\right)$. Determinations of thiobarbituric acid-reactive substances (TBARS) were done at $\mathrm{T} 0$ (production day) and T4, T7 and T10 days of refrigerated storage, respectively. Three repetitions of the mini hamburgers were produced for each time of storage and formulation.

The TBARS analysis was conducted in accordance with the Vyncke (1970) methodology. Briefly, a $2.5 \mathrm{~g}$ sample was homogenized (T25 digital Ultra-Turrax ${ }^{\circledR}$, IKA, German) with $10 \mathrm{~mL}$ of $7.5 \%$ trichloroacetic acid solution and $0.25 \mathrm{~mL}$ of $0.2 \%$ BHT solution. Subsequently the homogenate was filtered using Whatman \#1 filter paper. The filtrate was mixed in equal amounts to $0.02 \mathrm{M}$ thiobarbituric acid solution, and the mixture was heated in a water bath $\left(80^{\circ} \mathrm{C}\right)$ for $40 \mathrm{~min}$. The sample was then cooled and the color was spectrophotometrically measured at $538 \mathrm{~nm}$. The results were expressed in $\mathrm{mg}$ of malondialdehyde (MDA) per Kg of sample (mg MDA/Kg).

\subsection{Statistical analysis}

The results were expressed as mean $( \pm)$ standard deviation. The effect of the hydrolysis time on protein values, $\mathrm{DH}$ and antioxidant activity was assessed (ORAC, FRAP, TEAC), as well as the effect of adding antioxidants on the production of TBARS in the mini hamburgers. The data were tested by analysis of variance (ANOVA), followed by the Tukey test. The level of $\mathrm{p}<0.05$ was considered significant.

\section{Results and discussion}

\subsection{Characterization of the hydrolysates}

The percentage of crude protein in the ground feedstock (head and carcass) was $42.35 \%$ in a dry base ( $11.82 \%$ in wet base) and these results agreed with those reported in the literature (Roslan et al., 2014; Silva et al., 2014).

The hydrolysis ensured total recovery of the protein from the raw material; after the enzymatic reaction the mean protein content of the WLH samples was $45.33 \%$ (Table 1). It was also found that the hydrolysis time did not affect significantly the protein recovery from the samples ( $p>0.05$ ), corroborating with the literature which shows that enzymatic hydrolysis does not promote any change in protein nitrogen content, but does increase protein digestibility (Li et al., 2010). The proteolysis of fish by-products promotes the breaking of peptide bonds, thus contributing toward the solubilisation of the protein fraction and resulting in two fractions: one soluble and the other insoluble. The insoluble fraction consists of bones and other components not hydrolysed by proteases, whereas the soluble fraction is composed mainly of peptides (Silva et al., 2014).

In the present study it was found that hydrolysis associated with centrifugation and freeze drying $(\mathrm{CLH})$ promoted a high
Table 1. Percentage of protein and degree of hydrolysis of the Nile tilapia head and carcass hydrolysate produced with different times of hydrolysis.

\begin{tabular}{ccccc}
\hline & WLH & & \multicolumn{2}{c}{ CLH } \\
\cline { 1 - 2 } \cline { 5 - 5 } Sample & Protein $(\%)$ & & Protein $(\%)$ & Degree hydrolysis $(\%)$ \\
\hline H40 & $46.82 \pm 3.78$ & & $76.20 \pm 3.24$ & $19.5 \pm 1.07^{\mathrm{CD}}$ \\
H80 & $45.95 \pm 7.04$ & & $79.07 \pm 5.07$ & $21.52 \pm 0.56^{\mathrm{BCD}}$ \\
H120 & $44.45 \pm 1.28$ & & $78.68 \pm 2.15$ & $23.53 \pm 1.99^{\mathrm{ABCD}}$ \\
H160 & $44.96 \pm 8.7$ & & $80.96 \pm 5.00$ & $24.85 \pm 2.25^{\mathrm{ABC}}$ \\
H200 & $44.2 \pm 1.65$ & & $78.88 \pm 1.61$ & $26.13 \pm 0.75^{\mathrm{AB}}$ \\
H240 & $45.57 \pm 2.05$ & & $80.01 \pm 2.03$ & $25.72 \pm 1.28^{\mathrm{AB}}$ \\
$p$ & 0.995 & & 0.859 & 0.001 \\
\hline
\end{tabular}

$p$ : $\mathrm{p}$ value by ANOVA. The mean averages with values $\mathrm{p}<0.05$ were tested by Tukey and follow, represented by uppercase letters.

concentration of protein content, which reached a final mean percentage of $78.97 \%$. Therefore, based on these results one can assert that the processing used was efficient in protein recovery and concentration, ensuring total usage of the proteins considered as industrial waste. Other authors (Roslan et al., 2014; Silva et al., 2014) have obtained similar results for hydrolysate of same type of raw material.

As was expected, the hydrolysis time promoted differences in the degree of hydrolysis (DH) of the samples $(\mathrm{p}=0.001)$. The $\mathrm{DH}$ results were demonstrated by the difference in the intensity of the hydrolysate peaks observed in the chromatographic profiles detected at 214 and $280 \mathrm{~nm}$ (Figure 2). The chromatograms showed that the peptides related to the majority of the peaks eluted between 7 and 15 minutes, a region of average hydrophobicity. However, the increase in hydrolysis time promoted an increase in the intensity of the peaks, primarily those eluted at 8,9,11,13 and 16 minutes in the profiles with detection at $214 \mathrm{~nm}$ and at $8,9,11$ and 15 minutes with detection at $280 \mathrm{~nm}$. This hydrolysate profile might be explained by the broad specificity of Alcalase ${ }^{\circledast}$, an endopeptidase that splits bonds within the polypeptide chain, mainly producing small and medium-sized peptides (Liu et al., 2010).

The $\mathrm{DH}$ is an indicator of the efficiency of the hydrolysis (Foh et al., 2010) and normally after quick initial reaction phase the rate of hydrolysis tends to diminish, subsequently entering the stationary phase (Hoyle \& Merritt, 1994), which can be observed in this study, considering that at 40 minutes of hydrolysis (H40) the DH was $19.5 \%$, at 160 minutes (H160) it was $24.85 \%$ and at 240 minutes of reaction the DH was $25.72 \%$. In relation to other studies involving tilapia protein hydrolysates with Alcalase ${ }^{\circledR}$, the results of $\mathrm{DH}$ were highly variable (from 7.5\% to $85.3 \%)$. This variation suggests differences in the methods, as well as in the hydrolysis conditions used (Daud et al., 2013; Daud et al., 2015; Fan et al., 2012; Foh et al., 2010; Roslan et al., 2014; Silva et al., 2014). In this context, the DH results obtained by Roslan et al. (2014) support those of the present study, since the reaction conditions, DH analysis method, as well as the enzyme and feedstock were similar.

\subsection{Antioxidant activity of the hydrolysates}

Fish products are sources of high quality and highly digestible proteins and hydrolysis of these proteins produces biological active peptides, with antioxidant potential being one 
Bernardi et al.
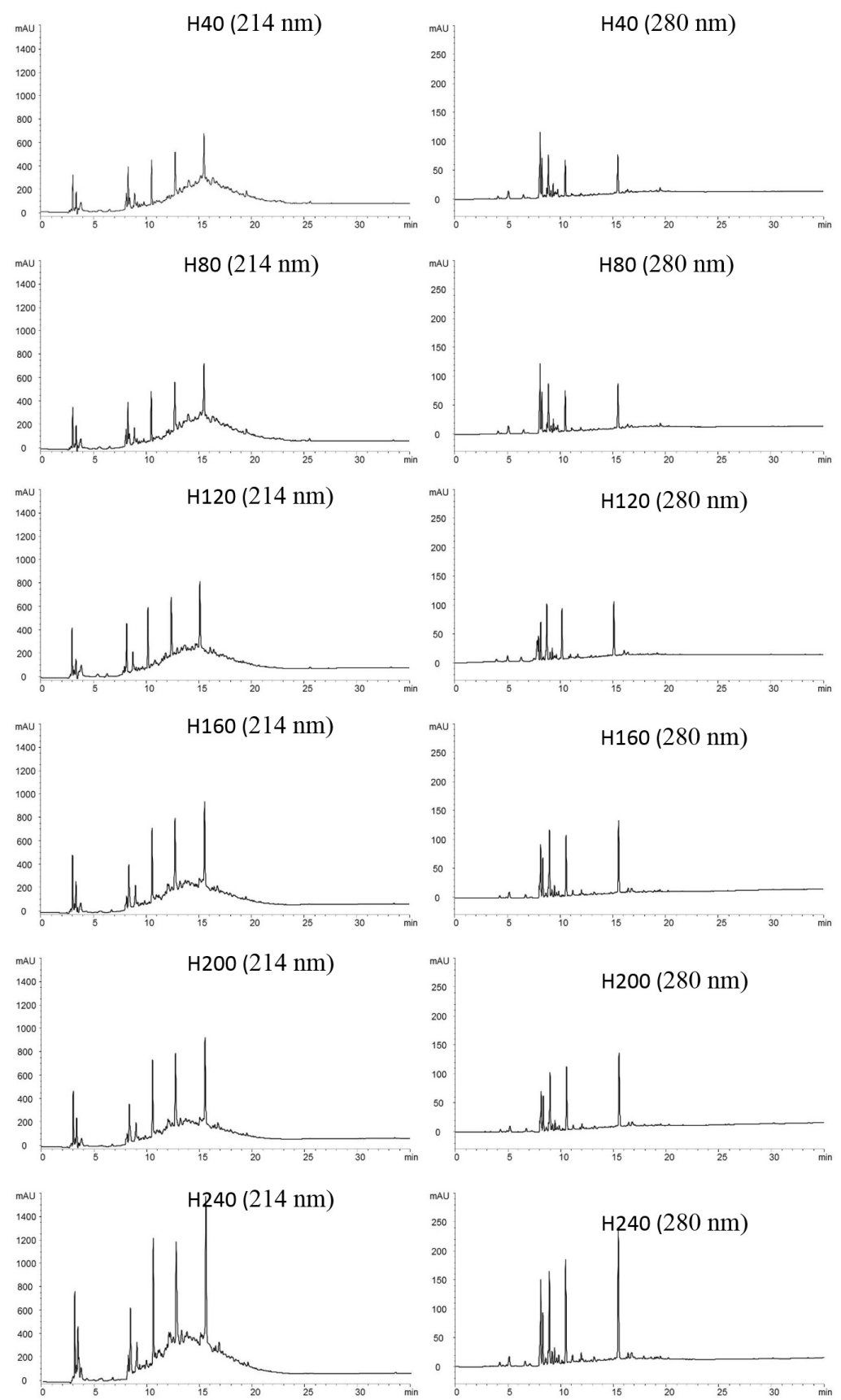

Figure 2. High-performance liquid chromatography of Nile tilapia hydrolysates produced by Alcalase ${ }^{\circledR}$ with different times of hydrolysis.

of the main factors to generate its bioactivity (Samaranayaka \& Li-Chan, 2011).

The amino acid composition of the feedstock and the hydrolysis conditions are determinant factors in the peptide profile of the hydrolysates, which directly influences the antioxidant capacity (Girgih et al., 2015; Wiriyaphan et al., 2015).

To determine the antioxidant potential of the hydrolysates, the FRAP and ABTS tests were used to assess the electron transfer capacity and the ORAC test was used to assess the $\mathrm{H}+$ transfer capacity (Huang et al., 2005). The results of the antioxidant activity of the hydrolysates are presented in Table 2.
Table 2. Antioxidant activity measured by ORAC, ABTS and FRAP of (centrifuged and dried) hydrolysate of Nile tilapia head and carcass produced by Alcalase ${ }^{\circledR}$ with different times of hydrolysis.

\begin{tabular}{cccc}
\hline Sample & ORAC $\left(\mu \mathrm{M} \mathrm{TE} / \mathrm{g}^{*}\right)$ & ABTS $\left(\mu \mathrm{M} \mathrm{TE} / \mathrm{g}^{*}\right)$ & $\mathrm{FRAP}\left(\mu \mathrm{M} \mathrm{TE} / \mathrm{g}^{*}\right)$ \\
\hline $\mathrm{H} 40$ & $331.25 \pm 9.87$ & $61.48 \pm 7.22$ & $74.83 \pm 7.63$ \\
$\mathrm{H} 80$ & $305.26 \pm 35.10$ & $69.77 \pm 10.53$ & $77.27 \pm 10.39$ \\
$\mathrm{H} 120$ & $327.48 \pm 43.96$ & $64.73 \pm 16.75$ & $67.89 \pm 12.1$ \\
$\mathrm{H} 160$ & $349.36 \pm 59.92$ & $69.27 \pm 8.32$ & $68.96 \pm 4.2$ \\
$\mathrm{H} 200$ & $337.95 \pm 40.66$ & $70.10 \pm 11.37$ & $64.09 \pm 16.49$ \\
$\mathrm{~h} 240$ & $303.43 \pm 10.38$ & $72.26 \pm 18.31$ & $87.91 \pm 8.41$ \\
$P$ & 0.564 & 0.234 & 0.086 \\
\hline p: $\mathrm{p}$ value by ANOVA. ${ }^{*}$ The results are expressed in $\mu \mathrm{M}$ of Trolox equivalent $(\mathrm{TE})$ per \\
gram $(\mu \mathrm{M}$ TE/g) of sample.
\end{tabular}


In all the methods used it was verified that the hydrolysis time and consequently the $\mathrm{DH}$ had no interference in the antioxidant activity of the hydrolysates $(\mathrm{p}>0.05)$. However some authors (Daud et al., 2013; Daud et al., 2015; Raghavan et al., 2008) have shown that the $\mathrm{DH}$ can influence the antioxidant potential of peptides formed in the hydrolysis of tilapia muscle proteins.

The ORAC results obtained were similar to those achieved for mussel hydrolysate (Park et al., 2014), as well as for hydrolysates of flaxseed protein (Silva et al., 2013) and oat (Tsopmo et al., 2010) which used Alcalase ${ }^{\circledR}$ as the enzyme. Girgih et al. (2015) and Girgih et al. (2015) found that salmon and cod hydrolysates presented higher amounts of ORAC than those found in the present study.

The evaluated hydrolysates of tilapia processing by-products showed high FRAP activity and ABTS radical cation. Other authors (Choonpicharn et al., 2014; Yarnpakdee et al., 2015) have shown elevated FRAP activity in hydrolysates produced with tilapia muscle and skin. The ABTS results presented here support those obtained by Raghavan et al. (2008) and are lower than those of Yarnpakdee et al. (2015), both based on tilapia muscle hydrolysates.

As a rule low molecular weight peptides display a greater capacity to eliminate hydroxyl radicals (Lee et al., 2010) and are able to expose more lateral chains, able to donate electrons with greater facility and therefore become more accessible to free radicals (Wiriyaphan et al., 2015). On the other hand, it is important to underline that despite smaller peptides being more efficient, some authors (Girgih et al., 2015) have found that non fractioned hydrolysates, like that produced in our study, show a greater FRAP, indicating a synergistic effect between peptides of different molecular weights.

The size of the peptide and the sequence of amino acids in the structure are all essential factors for their antioxidant activity (Samaranayaka et al., 2010; Wiriyaphan et al., 2015). Literature shows that peptides containing hydrophobic residues, including His, Met and Cys, are determinant in the hydroxyl radical neutralization capacity (Hernández-Ledesma et al., 2005), while the presence of aromatic residues (Tyr, Trp and Phe) give the peptide higher capacity to donate electrons (Girgih et al., 2015; Wiriyaphan et al., 2015).

In the hydrolysates of the present study the antioxidant activity probably derives from both the presence of aromatic amino acid residues, exhibited by the presence of peaks in the profiles with detection at $280 \mathrm{~nm}$, and the presence of peptides of average hydrophobicity eluted in the profiles with detection at $214 \mathrm{~nm}$. (Figure 2).

High quantities of hydrophobic amino acids (Ala, Val, Leu, Cys, Trp, Pro and Ile) in the peptides also offers structural properties that can improve interactions with lipidic foods, and help increase the admission of peptides in target organs by means of hydrophobic interactions with membranes (Girgih et al., 2015).

Comparing the three methods to assess antioxidant activity, it was found that the lowest results in UM TE per $g$ of sample were those determined by the FRAP and ABTS methods, and the highest results by the ORAC method. Therefore, the main mechanism of antioxidant action of the tilapia hydrolysates is possibly by means of hydrogen atom transfer.

Furthermore, the greatest ORAC values suggest that the tilapia hydrolysate peptides may be good in vivo antioxidants, since this is the method that presented the best correlation with physiological conditions (Magalhães et al., 2008).

\subsection{Application of the hydrolysate in meat product and assessment of TBARS production}

Lipidic oxidation causes nutritional losses and reduces the shelf life of the food products, furthermore the consumption of oxidized products can cause cellular injury (Girgih et al., 2015). Free radicals are normally formed in the aqueous phase of foods, primarily by Fenton reactions, and then migrate to the lipidic phase where they stimulate oxidation (Brewer, 2011). Amino acids, peptides and proteins possess a surfactant capacity and are capable of acting in the oil-water interface, where they present antioxidant activity and could be an excellent antioxidant option for application in food systems.

Lipidic oxidation is a spontaneous and inevitable process in meat and meat products. The mini hamburger produced with pork meat and fat with a high PUFA and especially $\omega$-3 content, is a good product model to assess this process. The presence of PUFA and $\omega-3$, as well as the grinding and addition of $\mathrm{NaCl}$ contributed toward the generation of a pro-oxidant state. The choice of $\mathrm{H} 200$ for this test was made randomly, considering that all the hydrolysates produced presented statistically similar antioxidant activity. Figure 3 shows the results of the TBARS analyses of the mini hamburgers (MHC, MHBHT, MHH) stored for 10 days.

With 4 days' and 7 days' storage only BHT (0.02\%) presented antioxidant activity capable of delaying lipidic oxidation ( $\mathrm{p}<0.001)$, with the malondialdehyde (MDA) concentration being statistically equal in the MHC and MHH samples and statistically lower in the MHBHT sample. With 10 days' storage the hydrolysate and BHT presented a significant antioxidant effect and all the samples differed $(\mathrm{p}<0.001)$, with the lowest MDA

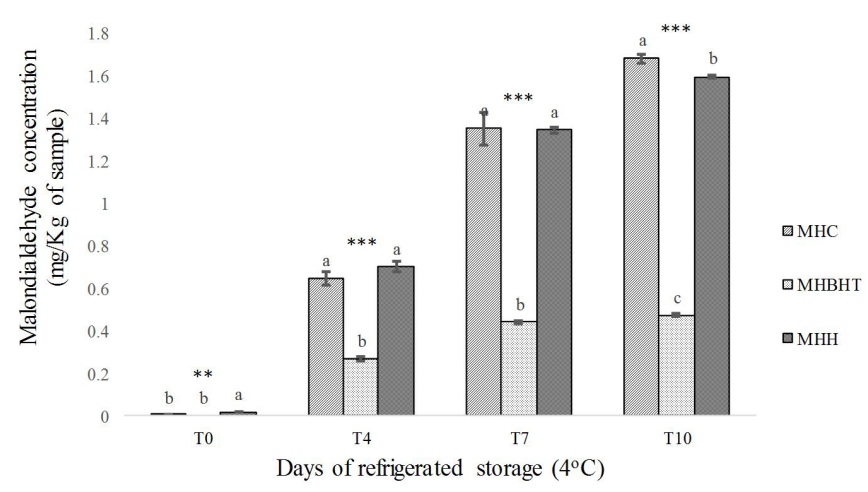

Figure 3. Presence of thiobarbituric acid-reactive substances (TBARS), expressed in $\mathrm{mg}$ of malondialdehyde ( $\mathrm{mg} / \mathrm{Kg}$ of sample). The samples analysed were: a mini-hamburgers produced without antioxidant (MHC), same product added of $1 \%$ tilapia hydrolysate $(\mathrm{MHH})$ and same mini-hamburger added of $0.02 \%$ of butylhydroxytoluene (MHBHT). $\left.{ }^{* *}: \mathrm{p}<0.01,{ }^{* * *}: \mathrm{p}<0,001\right)$. 
value being found in the MHBHT sample, followed by the MHH sample and the greatest MDA value being in the MHC sample.

The results suggest that the hydrolysate of tilapia processing by-products has an antioxidant effect, however, as expected, it is less expressive than that found in the synthetic antioxidant (BHT). It was also found that the hydrolysate had a delayed antioxidant effect (after 7 days of storage at $4{ }^{\circ} \mathrm{C}$ ).

Similar results regarding delayed antioxidant effect of protein hydrolysates on food products models, were also observed by other authors (Peña-Ramos \& Xiong, 2003; Sakanakaet al., 2004). Sakanaka et al. (2004) prepared cookies with a high concentration of linoleic acid and observed that from the third day of storage there was a considerable increase in the amount of peroxide in the samples. The same authors found that hydrolysed egg protein significantly reduced the production of peroxides only after the seventh day of storage, under the same conditions. Likewise, Peña-Ramos \& Xiong (2003) also found that pork patties added of hydrolysed soybean protein showed significantly lower production of conjugated dienes compared to the control after 7 days of storage.

Other authors (Dekkers et al., 2011; Raghavan \& Kristinsson, 2008) also reported antioxidant effect of the protein hydrolysate of tilapia on food systems. Raghavan \& Kristinsson (2008) used a model system of washed tilapia muscle, and found that the tilapia protein hydrolysate was capable of acting as antioxidant agent only after the third day of storage, moreover, suggested that the intensity and speed of antioxidation in the system was dependent on the type of enzyme and the degree of hydrolysis. However in a later study (Dekkers et al., 2011) demonstrated that tilapia protein hydrolysate, showed antioxidant effect in mahi mahi (Coryphaena hippurus) filets, but found that the fractionation of peptides by their molecular weight had no effect on increasing the hydrolysate's capacity to delay oxidation.

Despite the promising results at 10 days of storage, further studies are still required in different food matrixes to provide greater understanding of the antioxidant activity of peptides produced during fish protein hydrolysis. It should be highlighted that there are many in vitro studies in this area, yet in vivo works and studies in food systems remain scarce. Furthermore, consumer evaluations are also scarce, but of great importance, especially in the case of adding these hydrolysates to food products, as it is known that the increased $\mathrm{DH}$ can produce bitter-tasting peptides, which can reduce product acceptability (Halldorsdottir et al., 2014; Yarnpakdee et al., 2015).

\section{Conclusions}

By means of hydrolysis with Alcalase ${ }^{\circledast}$, it was possible to recover proteins that were considered residues or by-products of the Nile tilapia processing. In addition to protein recovery, hydrolysis also promoted the formation of highly antioxidant peptides in vitro and the enzymatic reaction time did not interfered in the results.

The hydrolysate produced revealed potential for use as an antioxidant in human diet, bearing in mind that its antioxidant action was engaged primarily through hydrogen atom transfer reactions, as well as presenting promising results in relation to its application as an antioxidant for food products.

Therefore, the results obtained have strengthened the economic, environmental and nutritional importance of the work and reinforced the need for new investigations in order to achieve a better understanding of the actions and usefulness of these compounds in vivo in animal diets and in food products.

\section{Acknowledgements}

The authors would like to thank the National Counsel of Technological and Scientific Development (CNPq - process 453854/2013-3) and the company Falbom Agroingustrial Ltda. for all their support in the development of this study.

\section{References}

Association of Official Analytical Chemists - AOAC. (1995). Official methods of analysis of the AOAC International (16th ed.). Virgínia: AOAC.

Benzie, I. F., \& Strain, J. J. (1996). The ferric reducing ability of plasma (FRAP) as a measure of "antioxidant power": the FRAP assay. Analytical Biochemistry, 239(1), 70-76. http://dx.doi.org/10.1006/ abio.1996.0292. PMid:8660627.

Bernardi, D. M., Bertol, T. M., Pflanzer, S. B., Sgarbieri, V. C., \& Pollonio, M. A. R. (2016). $\omega-3$ in meat products: Benefits and effects on lipid oxidative stability. Journal of the Science of Food and Agriculture, 96(8), 2620-2634. http://dx.doi.org/10.1002/jsfa.7559. PMid:26676414.

Brewer, M. S. (2011). Natural antioxidants: sources, compounds, mechanisms of action, and potential applications. Comprehensive Reviews in Food Science and Food Safety, 10(4), 221-247. http://doi. org/10.1111/j.1541-4337.2011.00156.x.

Choonpicharn, S., Jaturasitha, S., Rakariyatham, N., Suree, N., \& Niamsup, H. (2014). Antioxidant and antihypertensive activity of gelatin hydrolysate from Nile tilapia skin. Journal of Food Science and Technology, 52(5), 3134-3139. http://dx.doi.org/10.1007/s13197014-1581-6. PMid:25892821.

Daud, N. A., Babji, A. S., \& Yusop, S. M. (2013). Antioxidant activities of red tilapia (Oreochromis niloticus) protein hydrolysates as influenced by thermolysin and alcalase. AIP Conference Proceedings, 1571, 687-691. http://dx.doi.org/10.1063/1.4858734.

Daud, N. A., Babji, A. S., \& Yusop, S. M. (2015). Effects of enzymatic hydrolysis on the antioxidative and antihypertensive activities from red tilapia fish protein. Journal of Nutrition \& Food Sciences, 5(387). http://dx.doi.org/10.4172/2155-9600.1000387.

Dávalos, A., Gómez-Cordovés, C., \& Bartolomé, B. (2004). Extending applicability of the Oxygen Radical Absorbance Capacity (ORACFluorescein) assay. Journal of Agricultural and Food Chemistry, 52(1), 48-54. http://dx.doi.org/10.1021/jf0305231. PMid:14709012.

Dekkers, E., Raghavan, S., Kristinsson, H. G., \& Marshall, M. R. (2011). Oxidative stability of mahi mahi red muscle dipped in tilapia protein hydrolysates. Food Chemistry, 124(2), 640-645. http://dx.doi. org/10.1016/j.foodchem.2010.06.088.

Dieterich, F., Boscolo, W. R., Pacheco, M. T. B., Silva, V. S. N., Gonçalves, G. S., \& Vidotti, R. M. (2014). Development and characterization of protein hydrolysates originated from animal agro industrial byproducts. Journal of Dairy, Veterinary \&. Animal Research, 1(2), 1-7.

Fan, J., He, J., Zhuang, Y., \& Sun, L. (2012). Purification and identification of antioxidant peptides from enzymatic hydrolysates of tilapia 
(oreochromis niloticus) frame protein. Molecules, 17(11), 12836-12850. http://dx.doi.org/10.3390/molecules171112836. PMid:23117426.

Foh, M. B. K., Amadou, I., Foh, B. M., Kamara, M. T., \& Xia, W. (2010). Functionality and antioxidant properties of tilapia (Oreochromis niloticus) as influenced by the degree of hydrolysis. International Journal of Molecular Sciences, 11(4), 1851-1869. http://dx.doi. org/10.3390/ijms11041851. PMid:20480046.

Girgih, A. T., He, R., Hasan, F. M., Udenigwe, C. C., Gill, T. A., \& Aluko, R. E. (2015). Evaluation of the in vitro antioxidant properties of a cod (Gadus morhua) protein hydrolysate and peptide fractions. Food Chemistry, 173, 652-659. http://dx.doi.org/10.1016/j. foodchem.2014.10.079. PMid:25466072.

Halldorsdottir, S. M., Sveinsdottir, H., Gudmundsdottir, A., Thorkelsson, G., \& Kristinsson, H. G. (2014). High quality fish protein hydrolysates prepared from by-product material with Fucus vesiculosus. Journal of Functional Foods, 9, 10-17. http://dx.doi.org/10.1016/j.jff.2014.04.009.

Hernández-Ledesma, B., Dávalos, A., Bartalomé, B., \& Amigo, L. (2005). Preparation of antioxidant enzymatic hydrolysates from alphalactalbumin and beta-lactoglobulin. Identification of active peptides by HPLC-MS/MS. Journal of Agricultural and Food Chemistry, 53(3), 588-593. http://dx.doi.org/10.1021/jf048626m. PMid:15686406.

Hoyle, N. T., \& Merritt, J. H. (1994). Quality of fish protein hydrolysates from herring (Clupea harengus). Journal of Food Science, 59(1), 7679. http://dx.doi.org/10.1111/j.1365-2621.1994.tb06901.x.

Huang, D., Boxin, O. U., \& Prior, R. L. (2005). The chemistry behind antioxidant capacity assays. Journal of Agricultural and Food Chemistry, 53(6), 1841-1856. http://dx.doi.org/10.1021/jf030723c. PMid:15769103.

Lee, S. J., Kim, E. K., Hwang, J. W., Oh, H. J., Cheong, S. H., Moon, S. H., Jeon, B. T., Lee, S. M., \& Park, P. J. (2010). Purification and characterisation of an antioxidative peptide from enzymatic hydrolysates of duck processing by-products. Food Chemistry, 123(2), 216-220. http://dx.doi.org/10.1016/j.foodchem.2010.04.001.

Li, Z. Y., Youravong, W., \& H-Kittikun, A. (2010). Protein hydrolysis by protease isolated from tuna spleen by membrane filtration: a comparative study with commercial proteases. LWT - Food Science and Technology, 43(1), 166-172. http://dx.doi.org/10.1016/j. lwt.2009.07.002.

Liu, Q., Kong, B., Xiong, Y. L., \& Xia, X. (2010). Antioxidant activity and functional properties of porcine plasma protein hydrolysate as influenced by the degree of hydrolysis. Food Chemistry, 118(2), 403-410. http://dx.doi.org/10.1016/j.foodchem.2009.05.013.

Magalhães, L. M., Segundo, M. A., Reis, S., \& Lima, J. L. F. C. (2008). Methodological aspects about in vitro evaluation of antioxidant properties. Analytica Chimica Acta, 613(1), 1-19. http://dx.doi. org/10.1016/j.aca.2008.02.047. PMid:18374697.

Nielsen, P., Petersen, D., \& Dambmann, C. (2001). Improved method for determining food protein degree of hydrolysis. Journal of Food Science, 66(5), 642-646. http://dx.doi.org/10.1111/j.1365-2621.2001. tb04614.x.

Park, S. Y., Ahn, C., \& Je, J. (2014). Antioxidant and anti-inflammatory activities of protein hydrolysates from Mytilus Edulis and ultrafiltration membrane fractions. Journal of Food Biochemistry, 38(5), 460-468. http://dx.doi.org/10.1111/jfbc.12070.

Peña-Ramos, E. A., \& Xiong, Y. L. (2003). Whey and soy protein hydrolysates inhibit lipid oxidation in cooked pork patties. Meat Science, 64(3), 259-263. http://dx.doi.org/10.1016/S0309-1740(02)00187-0. PMid:22063011.
Raghavan, S., \& Kristinsson, H. G. (2008). Antioxidative efficacy of alkali-treated tilapia protein hydrolysates: a comparative study of five enzymes. Journal of Agricultural and Food Chemistry, 56(4), 1434-1441. http://dx.doi.org/10.1021/jf0733160. PMid:18247531.

Raghavan, S., Kristinsson, H. G., \& Leeuwenburgh, C. (2008). Radical scavenging and reducing ability of tilapia (Oreochromis niloticus) protein hydrolysates. Journal of Agricultural and Food Chemistry, 56(21), 10359-10367. http://dx.doi.org/10.1021/jf8017194. PMid:18828605.

Re, R., Pellegrini, N., Proteggente, A., Pannala, A., Yang, M., \& RiceEvans, C. (1999). Antioxidant activity applying an improved ABTS radical cation decolorization assay. Free Radical Biology \& Medicine, 26(9-10), 1231-1237. http://dx.doi.org/10.1016/S0891-5849(98)003153. PMid:10381194.

Roslan, J., Yunos, K. F. M., Abdullah, N., \& Kamal, S. M. M. (2014). Characterization of fish protein hydrolysate from tilapia (Oreochromis Niloticus) by-product. Agriculture and Agricultural Science Procedia, 2, 312-319. http://dx.doi.org/10.1016/j.aaspro.2014.11.044.

Sakanaka, S., Tachibana, Y., Ishihara, N., \& Juneja, L. R. (2004). Antioxidant activity of egg-yolk protein hydrolysates in a linoleic acid oxidation system. Food Chemistry, 86(1), 99-103. http://dx.doi. org/10.1016/j.foodchem.2003.08.014.

Samaranayaka, A. G. P., \& Li-Chan, E. C. Y. (2011). Food-derived peptidic antioxidants: a review of their production, assessment, and potential applications. Journal of Functional Foods, 3(4), 229-254. http://dx.doi.org/10.1016/j.jff.2011.05.006.

Samaranayaka, A. G. P., Kitts, D. D., \& Li-Chan, E. C. Y. (2010). Antioxidative and angiotensin-I-converting enzyme inhibitory potential of a pacific hake (merlucclus productos) fish protein hydrolysate subjected to simulated gastrointestinal digestion and caco-2 cell permeation. Journal of Agricultural and Food Chemistry, 58(3), 1535-1542. http://dx.doi.org/10.1021/jf9033199. PMid:20085275.

Silva, F. G. D., O’Callagahan, Y., O’Brien, N. M., \& Netto, F. M. (2013). Antioxidant capacity of flaxseed products: the effect of in vitro digestion. Plant Foods for Human Nutrition, 68(1), 24-30. http:// dx.doi.org/10.1007/s11130-012-0329-6. PMid:23224443.

Silva, J. F. X., Ribeiro, K., Silva, J. F., Cahú, T. B., \& Bezerra, R. S. (2014). Utilization of tilapia processing waste for the production of fish protein hydrolysate. Animal Feed Science and Technology, 196, 96106. http://dx.doi.org/10.1016/j.anifeedsci.2014.06.010.

Tsopmo, A., Cooper, A., \& Jodayree, S. (2010). Enzymatic hydrolysis of oat flour protein isolates to enhance antioxidative properties. Advance Journal of Food Science and Technology, 2(4), 206-212.

Vyncke, W. (1970). Direct determination of the thiobarbituric acid value in trichloracetic acid extracts of fish as a measure of oxidative rancidity. Fette Seifen Anstrichmittel, 12(12), 1084-1087. http:// dx.doi.org/10.1002/lipi.19700721218.

Wiriyaphan, C., Xiao, H., Decker, E. A., \& Yongsawatdigul, J. (2015). Chemical and cellular antioxidative properties of threadfin bream (Nemipterus spp.) surimi byproduct hydrolysates fractionated by ultrafiltration. Food Chemistry, 167, 7-15. http://dx.doi.org/10.1016/j. foodchem.2014.06.077. PMid:25148952.

Yarnpakdee, S., Benjakul, S., Kristinsson, H. G., \& Kishimura, H. (2015). Antioxidant and sensory properties of protein hydrolysate derived from Nile tilapia (Oreochromis niloticus) by one- and two-step hydrolysis. Journal of Food Science and Technology, 52, 3336-3349. http://dx.doi.org/10.1007/s13197-014-1394-7. 